T H O U G H T S E G O in Augustine and Descartes 
Also by Gareth B. Matthews:

Philosophy and the Young Child

Dialogues with Children

Ammonius on Aristotle's "Categories" (trans., with S. Marc Cohen) 
Gareth B. Matthews

\section{THOUGHT'S EGO}

I N A U G UST I N

A N D DESCARTES

Cornell University Press

Ithaca and London 


\section{Copyright (C) 1992 by Cornell University}

All rights reserved. Except for brief quotations in a review, this book, or parts thereof, must not be reproduced in any form without permission in writing from the publisher. For information, address Cornell University Press, 124 Roberts Place, Ithaca, New York 14850.

First published 1992 by Cornell University Press.

International Standard Book Number 0-8014-2775-4

Library of Congress Catalog Card Number 92-52767

Printed in the United States of America

Librarians: Library of Congress cataloging information appears on the last page of the book.

(0) The paper in this book meets the minimum requirements of the American National Standard for Information SciencesPermanence of Paper for Printed Library Material. ANSI Z39.48-1984.

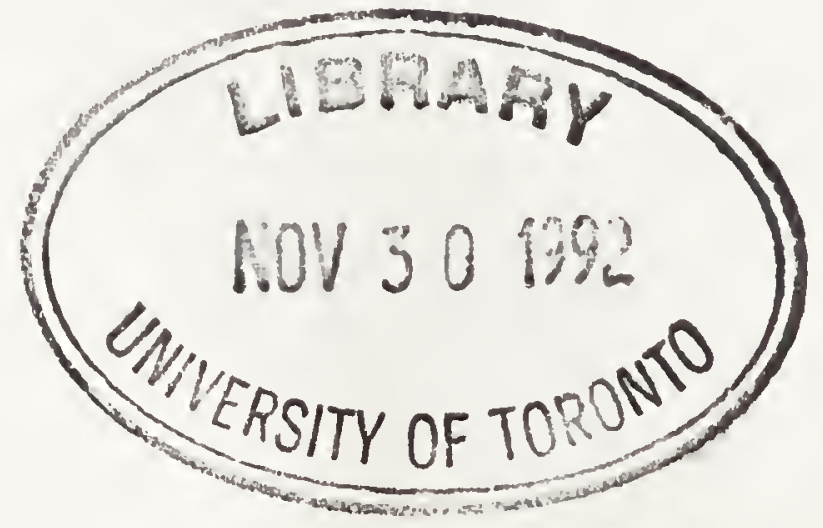


Hector-Neri Castañeda (1924-1991)

in memoriam 
Digitized by the Internet Archive in 2019 with funding from The Arcadia Fund 